\title{
Alaska Purchase Centennial: 1867-1967
}

\section{HERBERT H. RASCHE}

During i 967 , while Canada celebrates her first hundred years of Confederation and the world congregates in Montreal for Expo 67, another significant centennial is being celebrated in northern North America: that of Alaska's purchase from Russia by the United States of America.

For more than 200 years before i 867, Alaska had been a colony of the Russian Empire, of which it was the easternmost segment. On 30 March I 867 , by Treaty of Cession, the Emperor of Russia conveyed to the United States all the vast Russian holdings in America which today constitute the state of Alaska. The total price was $\$ 7,200$,ooo, or approximately two cents an acre, which was a small amount even in those days; the total of federal and state expenditures on the 1967 Centennial greatly exceeds this figure!

Among the many celebrations being held this year throughout the state is the Alaska 67 Centennial Exposition at Fairbanks. Historical exhibits depicting earlier days are combined with modern exhibits showing Alaska's economic, scientific, and cultural progress. Other cities as well are building permanent exhibition halls and community centres for initial use during the Alaska Purchase Centennial.

As this issue of Arctic commemorates the event, it is considered appropriate to review the historical background of the 1867 purchase, and developments over the following hundred years.

\section{EARLY EXPLORATION AND DEVELOPMENT OF RUSSIAN AMERICA}

Before 1867 , Russia had been extending and consolidating her control of the northern Pacific borderlands for more than two centuries. Russian exploration eastward across northern Asia, stimulated by the quest for furs, had reached the Pacific shores of Siberia in 1644 . In I 728 , Vitus Bering built a sailing vessel at Okhotsk, sailed northeastward, and found a passage separating Asia from North America. In $174 \mathrm{I}$ he made another voyage, this time with two vessels, the St. Peter and the St. Paul, which had been built at Petropavlosk, Kamchatka; the second vessel was under the command of Alexei Chirikov. After storms in which the two vessels lost contact, Chirikov sailed along the southeastern coast of Alaska almost to latitude $55^{\circ} \mathrm{N}$. and returned safely to Petropavlosk on 8 October i $74 \mathrm{I}$. Bering, on the other hand, reached the southern mainland coast of Alaska and sighted and named Mount St. Elias (see maps pp. 70-7I). Accompanying Bering on this voyage was the German physician and naturalist, Georg Wilhelm Steller. Near the end of the return voyage, the St. Peter was wrecked among the Komandorskiye Islands ("Commander Islands" on map, p. $7 \mathrm{I}$ ). Bering, with many of his crew, succumbed and was buried on the island that is today called Bering Island. Those who survived the

\footnotetext{
${ }^{1}$ Geographer, Research and Development Office, United States Army Arctic Test Center.
} 
winter built a smaller vessel from the wreckage of the St. Peter during the following spring and summer, and reached Petropavlosk on 26 August I 742 (Steller, in Golder 1925, pp. I 77-86). Steller brought back some sea otter skins, together with many other specimens, and prepared detailed scientific reports on the abundant animal life in the lands and waters to the east.

During the following decades numerous groups of fur traders ventured eastward to the Aleutians and beyond. After i 770 , control of the fur trade centred in several large companies. By I 784 , Gregory Shelikov had established a permanent Russian trading post on Kodiak Island. But it was not until i 786 , when Gerassim Pribilof discovered the uninhabited islands which now bear his name, that the Russians began to exploit the rich seal rookeries there (Hulley I 958, p. 68). After some years of competition and conflict, an imperial charter was granted in 1799 to a single monopoly, thenceforth called the Russian American Company. Although this was a private corporation, it was subject to direct government control from St. Petersburg. In I 799, under Alexander Baranof, an advance headquarters was established farther eastward at Sitka; later it became the actual headquarters. The fur trade was especially active in this area, despite much competition with British and American traders; and for the remainder of Baranof's tenure, which lasted until 18 i 8 , and under several successors, it remained active, but with diminishing profits. In later years, the successive governors of the company were naval officers, technically on detached service from military duty. The company clearly served as an instrument of imperial political policy and thereby maintained Russia's sovereignty in northwestern North America (Okun 1951, pp. 94-117). Some of the chief officials brought their wives and families to Alaska, and Sitka, as a result, became a centre of Russian culture as well as a busy port and a centre of small industries.

\section{WHY RUSSIA SOLD ALASKA TO THE UNITED STATES}

In the middle decades of the nineteenth century, Russian policy concerning its faraway colony changed. The reasons for the change were several: distances were great and control was difficult; the fur resources were becoming depleted; and paternalism, overstaffing, and easygoing methods at Sitka, at other posts in the colony, and at the home office in St. Petersburg, caused a steady increase in costs. Furthermore, during the Crimean War, though no fighting had taken place in the Russian-American colony, attacks had been made against Russian posts on the Siberian shore. As a result, Russia feared that Britain might soon go to war with her again and, in that event, seek to extend British rule over all the Russian lands in North America.

In Asia, during those decades, Western influence had grown rapidly. In I 84I, England had by force of arms won concessions for enlarged trade with China, and Hong Kong became a crown colony. The continuous demonstration of China's inability to resist foreign pressures encouraged 
Russia to seek control over the Amur Region in Far Eastern Asia (Tompkins I 945, p. I 70). In St. Petersburg, however, the conviction grew that Russia was weakened by overextension and should concentrate her efforts to maintain her boundaries and develop her strength within the confines of Europe and Asia. In these circumstances, Russia determined to seek a friendly Western power as purchaser of the Russian holdings in America; and yet, anxious to create a buffer zone between British North America and Siberia, Russia had no desire to sell to either Britain or Canada (Andrews I93i, p. I I I).

The United States, however, was not subject to the objections which Russia held with respect to Canada and Britain as prospective buyers of the Russian territories in America. Moreover, American interest in the Pacific had grown steadily during the early nineteenth century and many Americans considered it the manifest destiny of the United States to become a great power in the Pacific. Probably very few Americans in the decades before or after the Civil War were stronger believers in that manifest destiny than was William H. Seward. First as a senator and later as Secretary of State, he advocated a clear-cut Pacific policy that called for developing strong ties of friendship with China and Russia. He urged that the United States annex the Hawaiian Islands, obtain other islands farther west as refitting stations, obtain control of Alaska for strategic reasons, and dig an isthmian canal across Nicaragua. He was also convinced that the United States should purchase Cuba, the Virgin Islands, Greenland, and Iceland to provide for adequate outer defences in the Atlantic. Other considerations apart, the importance of Seward's strategic concepts has since been amply demonstrated; yet during his years in public office the only overseas territory acquired by the United States, other than Midway Island, was Alaska. Even the winning of Congressional approval for the purchase of Alaska was touch-and-go, and the wisdom of acquiring it was widely questioned at the time.

\section{NEGOTIATION OF PURGHASE}

Discussions about the possible sale of Russian America were opened by Baron Stoeckl, the Czar's Minister in Washington, in I857. By that time, however, the slavery question and the drive toward secession were already overshadowing all else, and when the Civil War began, further discussions concerning Alaska were out of the question. But when the war ended, both Stoeckl and Seward were more than ready to negotiate, the one eager to sell on any reasonable terms, the other eager to buy. In March I867, following three weeks of preparation and an authorizing cable from the Czar, the treaty was put into final form at Secretary Seward's home during an all-night work session; it was signed by Stoeckl and Seward at four in the morning on 30 March 1867 . There was a possibility that the Senate would adjourn that day and Seward was anxious to offer the treaty for ratification beforehand. In the Senate, however, other matters intervened, and active support for the purchase was by no means strong. But some days 


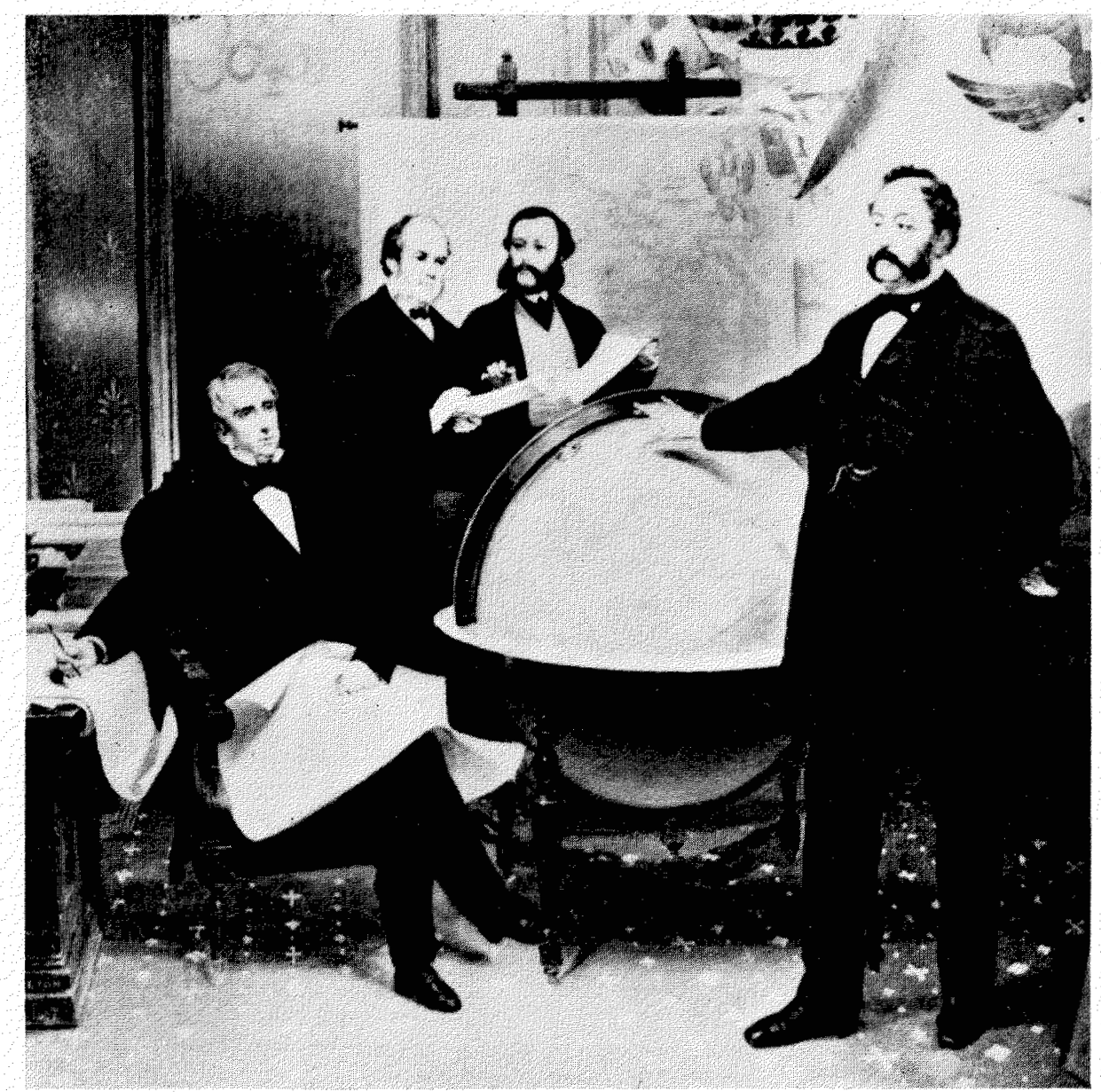

The Signing of the Treaty. Seward is seated; Baron Stoeckl is standing in front of the globe. (Reproduced from Alaska and Its History, edited by Morgan B. Sherwood. Seattle: University of Washington Press, I 967).

later, Senator Charles Sumner of Massachusetts, having made an exhaustive study of Alaska's geography and history, delivered a remarkable threehour speech in the Senate; this won sufficient additional votes to assure the two-thirds majority needed for ratification. It was as a result of Sumner's advocacy that the name "Alaska," a modification of the Aleut word $A l-a$-aska, meaning the "Great Land," was adopted for the new American colony. And yet in spite of Sumner's success, the House of Representatives did not finally vote the money to pay for the purchase until i 4 July I 868, long after the formal transfer had taken place, with appropriate ceremonies, at Sitka on 28 October 1867 .

\section{ESTABLISHMENT OF ALASKA'S BOUNDARIES}

The Treaty of Cession in 1867 defined the boundaries of Alaska as those 
that had been agreed upon in the British-Russian Treaty of 1825 . The negotiations which led to this latter treaty had been brought about by assertive, unilateral actions taken by the Russians during the preceding four years. On 4 September I 82 I, Czar Alexander I had issued an edict forbidding all foreign vessels to come within one hundred miles of the coast anywhere north of latitude $5^{\circ} \mathrm{N}$., except in cases of dire distress. This edict would have cut off all economic activity by non-Russians in Pacific coastal waters, or on land, anywhere north of the north end of Vancouver Island. Both the United States and Britain promptly protested, and thereafter both countries initiated negotiations at St. Petersburg.

In I 824, the United States concluded a treaty with Russia which recognized the right of the United States to navigate in all waters contiguous to Russian America and in all coastal creeks, for purposes of fishing and trading, for a period of ten years. The treaty established the southern boundary of Russia's sovereignty at $54^{\circ} 4 \mathrm{o}^{\prime} \mathrm{N}$., approximately the same latitude as the southernmost extremity of Alaska today.

The British-Russian Treaty of the next year had similar provisions, and, in addition, delineated the boundary between the holdings of the two countries. At the start of negotiations Russia announced claims to all of Alaska west of longitude $139^{\circ} \mathrm{W}$. Before 1825 , England had asserted claims to all of southeastern Alaska as far north as $59^{\circ} \mathrm{N}$. (Davidson I 903, p.59). These claims were based on explorations by Captain James Cook in 1778 and on extensive charting by Captain George Vancouver in I793-94. Russia, however, had actually occupied the region as far south as Sitka for a quarter-century. Also, in 1812 Russia had established the Ross Agricultural Colony near Bodega Bay, California, not far north of San Francisco. In southeastern Alaska, the Russian American Company desired firm control of the mainland strip, or lisiere, in order to retain part of the fur trade with the interior, a trade that was slipping more and more into the hands of the Hudson's Bay Company (Davidson igo3, pp. 59-62). In the end, Britain conceded control of the lisière to the Russian American Company by agreeing to a boundary which would run along the crest of the supposedly continuous coastal range, but which would be at no point more than ten marine leagues from the sea as measured following the sinuosities of the coastline (Davidson I 903, p. 8I ). Also, Britain agreed to the $54^{\circ} 4 \mathrm{o}^{\prime} \mathrm{N}$. boundary, thereby conceding all of Prince of Wales Island and the islands north of it to Russia. In exchange for these concessions, however, Russia agreed to settle the north-south interior boundary on a meridian two degrees farther west than it had claimed, i.e., at $14^{\circ}{ }^{\circ} \mathrm{W}$. instead of at $139^{\circ} \mathrm{W}$. This had the effect of placing much of the Klondike region, including the site of present-day Dawson, in Canada.

Article VI, a highly significant article in the British-Russian Treaty, granted British subjects transit rights between the interior and the Pacific shore "in perpetuity" (Davidson 1903, p. 82). After the sale of Alaska, however, the United States did not recognize the validity of this provision, 
and the British Foreign Office, to whom the Canadian government appealed for support, acceded to the American position, perhaps because Britain just then had its hands full with American claims arising out of the Civil War. Canadians today, urgently desiring freer access to Alaskan ports from northwestern Canada, are bringing this question up for re-examination.

No rights to the establishment of land posts or to trading activities had actually been granted by the British-Russian Treaty of 1825 , and troubles therefore arose over interpretation of the access rights supposedly granted. In 1839 , after extended negotiations involving the principal officers of both companies, a ten-year lease was given by the Russian American Company to the Hudson's Bay Company. The lease was carefully drawn, contained numerous provisions, and proved to be beneficial to both parties. In return for extensive trading rights, the Hudson's Bay Company agreed to fulfil the following conditions: first, to sell stipulated quantities of pelts from the mainland interior to the Russian American Company at reasonable prices; secondly, to sell quality trade goods and other supplies to the Russians and to carry these goods at a very low rate ( $£_{13}$ per ton) in Hudson's Bay Company ships from London to Sitka; and thirdly, to furnish the Russians with stipulated quantities of grain, butter, beef, ham, and other products from the Puget's Sound Agricultural Colony (Galbraith 1957, p. I 54).

Following the American purchase of Alaska and the further exploration of the coastal ranges it was recognized that demarcation of the southeastern boundary in accordance with the British-Russian Treaty of 1825 would be impossible, because there was not a continuous coastal range as had at first been supposed. At the close of the nineteenth century, when the gold rush to the Klondike was at its height, and control of the seaboard entrance to the routes to the mountain passes became important, Canada sought to have a modified boundary demarcated in such a way as to give her some portions of the coast. Difficulties cropped up in trying to agree on a commission or board to resolve the dispute that had developed, but finally the Alaska Boundary Tribunal was established, with three members from the United States, two from Canada, and one from England. In the negotiations, the United States claimed everything up to ten marine leagues inland from the uppermost reaches of tidal influence at the heads of the many narrow inlets, whereas the Canadians sought to have the seacoast construed as crossing the mouths of these inlets. One of the chief Canadian objectives was control of the head of Lynn Canal, which gives access to Dyea and Skagway and to the routes over the Chilkoot and White Passes to the Klondike. The Canadian claims did not prevail. The boundary, as finally decided and announced in I 903 , extends from major peak to major peak in many sections, and though it does lie well west of the boundary shown on early maps based on the British-Russian Treaty, it nevertheless gives the United States the entire mainland coast. When announced, the boundary decisions were, of course, highly unpopular in Canada (Hulley 1958, pp. 27I-76). 
In 1867 all the coast of Alaska had been explored, although along most of it little detailed surveying and charting had been done. Russian explorers had ascended some of the major rivers, such as the Yukon and Kuskokwim, for hundreds of miles, and Russian traders had established a few interior trading posts on riverine sites in western and southern Alaska. Russian control extended from the southern limits of Alaska all the way westward and northward to Kotzebue Sound and Cape Prince of Wales. The central and eastern interior, however, and the Brooks Range and Arctic Slope region to the north were beyond the zone of Russian occupation.

Deep in the interior of Alaska, where the Porcupine joins the Yukon, the Hudon's Bay Company as early as 1847 had established a trading post, well west of the Canadian boundary, and also far beyond the limits of Russian activity (Galbraith 1957 , pp. I6o-61). In the southeast, too, the Hudson's Bay Company up until 1867 had continued regularly to renew its lease of the lisière, or mainland coast.

During the years just before the purchase the United States and Britain, with strong Russian approval, had co-operated in making the survey for the intercontinental Western Union Telegraph line that was to extend across the Bering Strait to Siberia and thence westward to Europe. Although the successful completion of the North Atlantic cable in 1866 killed this project, the surveys for the overland route resulted in much new knowledge of the Alaskan interior. The director of the survey in Russian America was Robert Kennicott, the first trained scientist to visit the Yukon River (Brooks I953, pp. 242-45). He was accompanied by another scientist, William H. Dall, who took charge of the scientific program after Kennicott's untimely death at Nulato in I866. Dall's earliest reports describing the interior provided reliable information for the United States government at the time of the Alaska Purchase.

However, the Alaskan interior in 1867 was both largely unexplored and virtually unpopulated. Alaska was far removed from the populated East, in travel time as well as in miles, and despite her vast resources, as described by Sumner, and despite her strategic importance, as recognized by Seward, she was to draw very few new settlers during the three decades following the Alaska Purchase.

In this respect, in 1867 , Alaska was similar to much of the rest of interior North America. For example, the new Dominion of Canada in her Confederation year had few sizeable communities north or west of the upper Great Lakes; and her far northwest, like most of Alaska, was still the land of the native hunters, of the fur traders and missionaries, and of seasonal whalers in arctic waters. Moreover, much of the interior of the western United States also remained unpopulated and undeveloped; the first transcontinental railroad was being built in 1867 , but would not be completed until i 869. 
Map of the North Pacific region by the

St. Petersburg Academy of

Sciences I 758, incorpo-

rating theresults of Bering's

two expeditions. Repro-

duced from "Voyages et

Découvertes Faites par les

Russes le long des côtes de

la Mer Glaciale \& sur

l'Ocean Oriental, tant vers

le Japon que vers

l'Amérique," by G. P.

Muller. Amsterdam, i 766 .

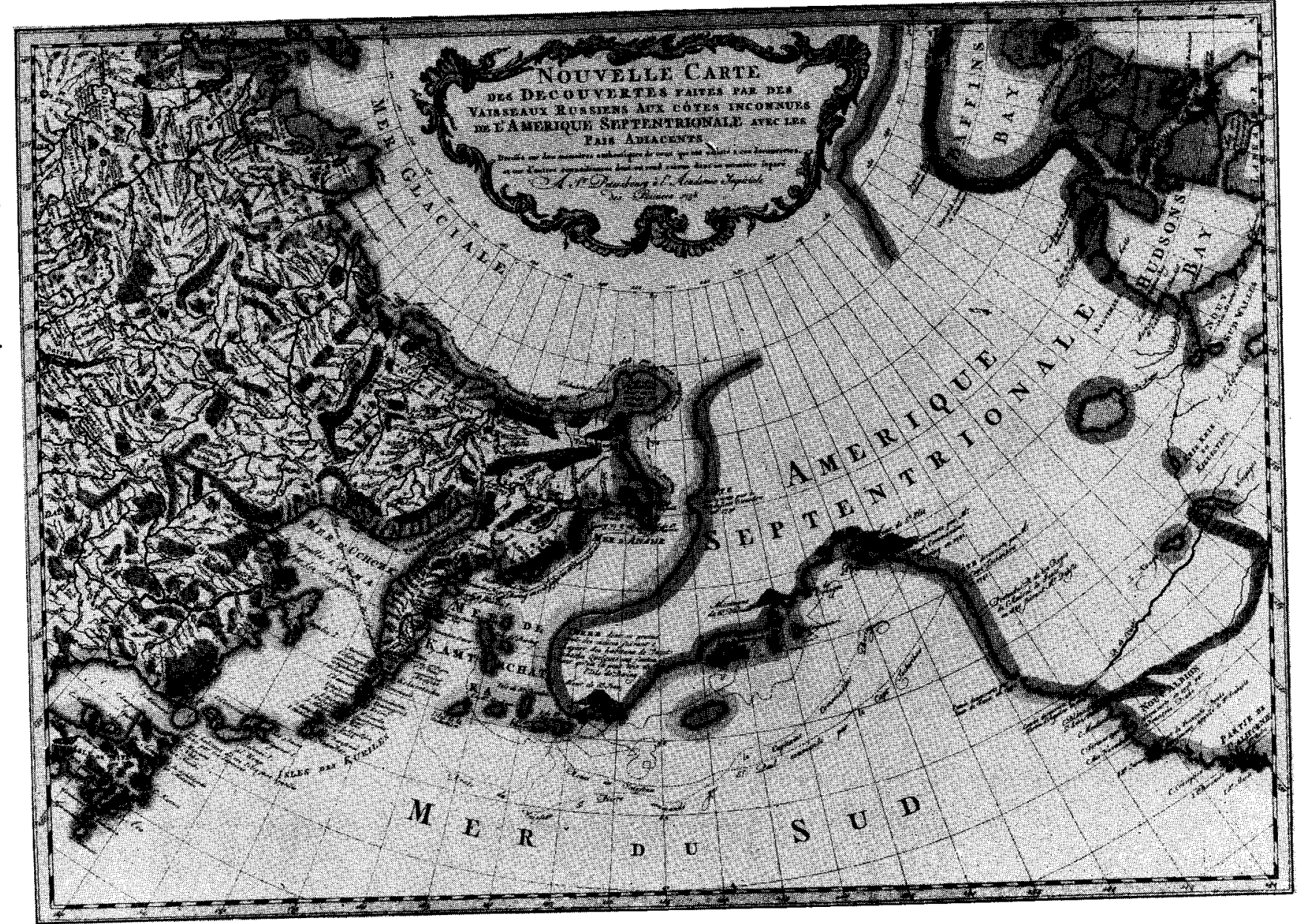




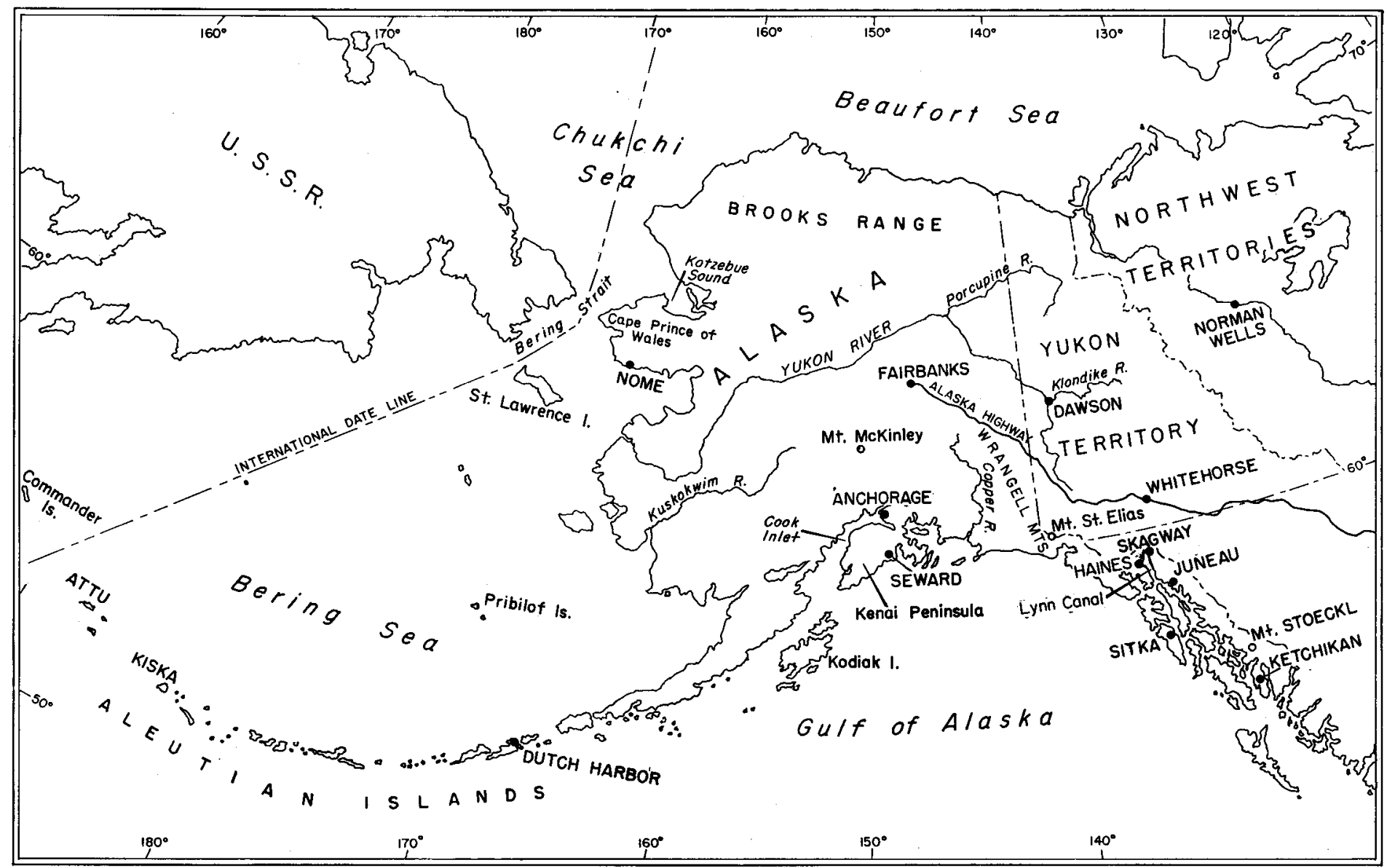

Map of Alaska, 1967. 
FIRST FORTY YEARS OF AMERICAN CONTROL: I 867-I 906

For three decades after purchasing Alaska, the American federal government gave little attention to its vast new colony (Gruening I959, pp. I 2-13). Nevertheless, scattered military posts were established and a number of significant explorations were made. Sealing rights in the Pribilofs were leased for twenty years to the Alaska Commercial Company, whaling was active but declining, and the first commercial salmon cannery was opened in 1878 . Steam navigation of the Yukon began in 1869 , when Captain Charles Raymond, U.S. Army Corps of Engineers, ascended to Fort Yukon and arranged for the British trading-post activities there to be withdrawn east of the border. The Anglican missionaries, however, continued their ministry at Fort Yukon until American Episcopalian missionaries were able to assume this charge some thirty years later (Cody I 113 , p. 274). American missionaries of several faiths extended their work actively along the coast.

The discovery of gold at Juneau in I 880 led to the development of the great Juneau-Treadwell operations there. In the upper Yukon Basin after I 880 active prospecting over a vast area was rewarded with occasional moderate strikes (Tompkins I 945, pp. 2 I 4-18). The Coast and Geodetic Survey received small appropriations to conduct limited programs, and in I 895 the Geological Survey received its first appropriation for field work in Alaska (Brooks I 953, p. 282). Mines and fisheries along the coast produced increasing millions of dollars each year, but very little of the wealth so produced remained in Alaska.

The spectacular gold strikes in the Klondike region of Canada (1 896), at Nome (1898), and at Fairbanks (1905), ushered in a new period. Thousands took the land route over the Chilkoot and White Passes to Dawson; others made the long trip by steamer up the Yukon. Within a few years the Dawson and Nome regions each had 50,00o people. Fairbanks had a slower growth but soon became important not only for gold but also as an interior crossroads and economic centre.

\section{EXPLOITATION AND CONSERVATION: I gO6-I 2}

The early igoo's witnessed the growth of a number of large companies. Among these was the Kennicott Copper Company which built its own Copper River and Northwestern Railroad to bring out the ore from its vast deposits in the Wrangell Mountains. Large fish cannery corporations developed, with each corporation controlling many canneries. Sea transportation, which provided the only commercial link with Alaska up until I 940, came under the control of a monopoly (Gruening I954, p. 235).

Two valuable resources, timber and coal, were exempted from widespread exploitation. As a national conservation measure the great timberlands of the southern coastal region were set aside as national forest reserves, and coal lands which at that time might have provided coal for developing local power and industry were withdrawn from entry (Gruening 1954, p. I30). 
Not until 1912 did Congress grant Alaska territorial status. The new legislature had very limited powers, and the federal bureaus continued to dominate many aspects of Alaskan life and economy.

Early in World War I many Alaskans enlisted in the Canadian forces, and many others later served in the American forces. By I 917 a few main highways had been constructed and in that year Mount McKinley National Park was established. The government-built Alaska Railroad from Seward to Fairbanks was completed in 1923, and Anchorage, built on Cook Inlet as a sea-land trans-shipment point, began its rapid growth.

The postwar years witnessed a steady decline in mining because of high costs and a decline in salmon packing because of depletion. Flying, however, developed rapidly.

The depression years in the early I930's were a time of development in Alaska: government-aided agricultural settlement in the Matanuska Valley made progress, and agriculture and grazing were extended on the Kenai Peninsula and in the Tanana Valley near Fairbanks. Mining surged forward when the price of gold rose almost 75 per cent in 1933, and territorial support of schools and other developments increased after the territory began to derive income from new taxes.

\section{ALASKA AND CONTINENTAL DEFENCE: WORLD WAR II AND AFTER}

After World War II had started, army installations, including Army Air Corps flying fields, were rapidly developed at Anchorage and Fairbanks, and naval bases were expanded at Sitka, Kodiak, and Dutch Harbor. Soon after Pearl Harbor, the Japanese made air attacks on Dutch Harbor and occupied Attu and Kiska. Attu was recaptured, after furious fighting, in 1943; the Japanese evacuated Kiska after heavy sea and air attacks later that same year. The war stimulated the building of the Alcan Highway as a co-operative Canadian-United States effort to connect a series of airfields and to provide a land supply route to Alaska. The Canol pipeline from Norman Wells to Whitehorse was also built during the war, as was a fourinch line from Skagway, at the head of Lynn Canal, to Whitehorse, in the interior. Hundreds of Russian pilots and other air personnel came to Ladd Field at Fairbanks and to other transfer points to receive lend-lease planes and other equipment to be flown to the U.S.S.R. (Hulley I958, pp. 335-46).

Later, the realities of the Cold War demanded continued development of defences in Alaska as well as in Canada. Large military and naval bases have had to be maintained, and another pipeline has been built, in this case from Haines, on the Lynn Canal, through British Columbia and the Yukon Territory and thence to Fairbanks. The construction of the DEW Line and of Ballistic-Missile Early Warning Stations (BMEWS), is now a familiar story. 
When at last statehood was achieved in 1959, amid much rejoicing, the great increase in local autonomy made available many new means of stimulating growth and development. Not the least of these means was the increased power to tax and, thereby, to retain for the state some portion of the large income derived from state resources by out-of-state corporations.

Maintenance of military defences continues, at great cost; and Federal funds are also received, as they are by other states, for education, highway construction, public health services, and many other purposes. Federal employment, both military and civilian, constituted 48 per cent of total employment in Alaska in 1960 (Rogers and Cooley 1962, p. 121). This picture is changing as a result of the development of several kinds of resource-based industries. The fisheries are expanding: in recent decades, the state, employing wise conservation practices, has rebuilt the salmon resource, and record packs are being made $(\$ 47,370$,ogo in 1965$)$. The harvest of other seafoods, notably king crab and halibut, amounts to \$24,000,00o annually. Lumbering has also expanded and large pulp mills have been built at Ketchikan and Sitka.

Mineral production has changed. On the one hand, the production of gold has declined greatly because of high mining costs. On the other hand, petroleum and natural gas production, especially in the Cook Inlet area, has increased phenomenally and, as is true elsewhere, these products are cutting into the market for coal. A new copper find at Bornite, in the Kobuk Valley, is expected to become a major producer; gravel, sand, and stone production for highway and building construction is also significant.

Alaska has a tremendous electric-power potential, both at coal and at water sites, and increased demand and lower prices for power are expected to go hand in hand. At Healy, in the Alaska Range, a minehead thermal plant designed to supply Fairbanks and other markets will open during this Centennial year. The huge proposed Rampart Dam project for the upper Yukon Basin has many supporters, although, as in the case of the opening of petroleum fields on the North Slope, little action can be expected until important questions related to native claims and economic feasibility are settled.

An active highway construction program continues not only to facilitate local and tourist travel but to open up new areas as well. A winter-haul trail from Fairbanks to Anaktuvuk Pass in the Brooks Range may be approved this year; and support in the legislature is stronger than ever before for a year-round road and railroad running to the north and then west from Fairbanks to Nome.

Alaskans believe strongly in education and support their schools generously. The State University, near Fairbanks, now celebrating its Golden Anniversary, has already attained stature as a centre of northern and Pacific research (Rae I 966 , pp. 39 ff.) and has strong community colleges in other cities. The Alaska Methodist University at Anchorage, even 
younger, also has a strong program at both the undergraduate and graduate levels.

The Good Friday Earthquake of 27 March 1964 wrought terrible havoc in Anchorage and other coastal cities and towns. Prompt and generous federal assistance and determined, confident local effort have effected a miracle of rehabilitation in most communities.

Today, most Alaskans, though they often seek and enjoy the wilderness, live in urban communities. Many of these communities retain characteristics which reflect their early pioneer histories, although most of them have grown rapidly in recent years and now display a modern aspect both in their central business districts and in their extensive new residential sections.

The need to settle native claims is becoming ever more imperative. Recently, the several native groups associated to form an Alaska-wide alliance which combines Thlinget Indian groups from the south, Athapascans from the interior, Aleuts from the southwest, and Eskimos from the west and north. The separate groups have filed claims to land areas totalling 70 per cent of all Alaska and are now making concerted efforts to obtain settlement. As settlement of these claims proceeds, much more extensive development should become possible in regions with valuable resources.

Many leaders in Alaskan affairs recognize the great desirability of reaching regional-development agreements with their Canadian neighbours, to improve communication and transport networks, to relax certain restraints on international commerce, and to provide outlets through Alaska for the Yukon and northern British Columbia.

Alaska has rapidly become an important international air crossroads for planes flying between Europe or eastern North America and the Orient. Liberal stop-over privileges for international travellers were instituted for the Centennial and afterward; this will enable increasing thousands to visit Alaska, to see this "Great Land," and, in the spirit of the Centennial, to "Look North to the Future."

\section{REFERENCES}

Andrews, C. L., I 93 I. The Story of Alaska. Seattle: Lowman and Hanford Co. $25^{8}$ pp.

BRoOKs, A. H., I953. Blazing Alaska's Trails. Washington, D.C.: University of Alaska and Arctic Institute of North America. 527 pp.

CoDy, A. H., I913. An Apostle of the North. London: Seeley Service. $3^{86} \mathrm{pp}$.

Golby, м. H., 1 939. A Guide to Alaska, Last American Frontier. New York: Macmillan. 427 pp. Davidson, george, 1903. The Alaska Boundary. San Francisco: Alaska Packers Association. $235 \mathrm{pp}$.

GAlbraith, J. S., I957. The Hudson's Bay Company as an Imperial Factor, I82 I-1869. Berkeley and Los Angeles: University of California Press. 500 pp. 
GOLDER, F. A., 1925. Bering's Voyages: an account of the efforts of the Russians to determine the relation of Asia and America. Vol. II. New York: American Geographical Society. $290 \mathrm{pp}$.

Gruening, E., I 954. The State of Alaska. New York: Random House. 606 pp. pp. 2-32.

hulley, c. H., 1958. Alaska: Past and Present. Portland, Ore.: Binfords and Mort. 422 pp.

KIMBLE, G. H. T., and D. GOOD, eds., I954. Geography of the Northlands. New York: American Geographical Society, and Wiley. 534 pp.

okun, s. B., I95I. The Russian-American Company, Carl Ginsburg, trans. Cambridge, Mass.: Harvard University. 3 I I pp.

RAE, K. M., 1966. Research in Alaska. Artic, 19: 39-47.

ROGERS, G. W., and R. A. COOLey, 1962. Alaska's Population and Economy. 2 Vols. Juneau: University of Alaska.

SEmyonov, y., (c. I963) Siberia: Its Conquest and Development. Montreal: International Publishers' Representatives. $4^{\mathrm{I}} 4 \mathrm{Pp}$.

shields, A. W., I967. The Purchase of Alaska. College, Alaska: University of Alaska Press. $208 \mathrm{pp}$.

TOMPkins, s. R., 1945. Alaska - Promyshlennik and Sourdough. Norman: University of Oklahoma Press. $35^{\circ}$ Pp. 